\title{
Short-term Changes in a Cottonwood-Ash- Willow Association on a Grazed and an Ungrazed Portion of Little Ash Creek in Cen- tral Arizona
}

\author{
ROBERT C. SZARO AND CHARLES P. PASE
}

\begin{abstract}
Recovery of a cottonwood-ash-willow association from overgrazing has been extremely limited over a 4-year period. Seedling reproduction and herbaceous cover has increased; however, overstory tree species composition has not changed. Tree growth was not affected by grazing. The younger, associated, codominant tree species differed in composition between the grazed and ungrazed plots.
\end{abstract}

Grazing is generally thought to have a negative impact on riparian zones (Ames 1977, Davis 1977, Platts 1979, Thomas et al. 1979). The reproduction of many riparian tree species is oftentimes virtually eliminated by grazing because young seedlings are preferred browse for cattle (Glinski 1977, Martin 1979). In order to document the effects of grazing on riparian vegetation, numerous exclosures have been set up in the riparian zones of the National Forests, in Arizona (Turner et al. 1980). This study examines recovery within one such exclosure, 2 and 4 years after fencing.

\section{Site Description}

The study area is along the Little Ash Creek on the Prescott National Forest, about $14.5 \mathrm{~km}$ east of Cordes, Ariz., at a longitude of $112^{\circ} 02^{\prime} 30^{\prime \prime}$ west and latitude of $34^{\circ} 23^{\prime} 10^{\prime \prime}$ north (T12N R3E S33-34). The study area is divided into 2 sections by an exclosure originally set up in 1975 to protect the riparian vegetation from cattle. The study site within the exclosure is at an elevation of 1,165 $\mathrm{m}$ and the grazed study area is at $1,170 \mathrm{~m}$. Both are in one of 3 range units, of approximately 3,300 ha each, that are grazed in rotation by a cow-calf herd of about 300 animal units. Riparian habitat represents less than $5 \%$ of the pasture where the study plots are located. Before 1975, both areas were subject to the same grazing pressure. After 1975, cattle were excluded from within the exclosure but not from the remainder of the drainage. The exclosure itself is approximately 16.5 ha ( 40 acres). The remainder of the pasture was grazed from March through June 1975 with 300 head of cattle and then again with 150 head in September and October. Thereafter, 300 head were grazed in November and December 1976, March through June 1977, November to February 1977-78, June through October 1978, and November through February 1979-1980. Average annual rainfall is about $430 \mathrm{~mm}$ (17 inches); June-September rainfall makes up $42 \%$, and November-March precipitation $44 \%$ of the year's total.

\section{Methods}

Two study sites along Little Ash Creek were selected-one within the livestock exclosure and the other $100 \mathrm{~m}$ upstream of the

\footnotetext{
Authors are research wildlife biologist and research ecologist, respectively, with USDA Forest Service, Rocky Mountain Forest and Range Experiment Station, Fort Collins, Colo. Szaro is at Station's Research Work Unit at Tempe in cooperation with Arizona State University. Pase is now retired, living in Tularosa, New Mexico.

Manuscript received November $1,1981$.
}

exclosure boundary. Four plots, 5- by $25-\mathrm{m}$, were selected parallel to the stream bed at each site. The initial plot was randomly located within the woody riparian vegetation, halfway between the stream bed and the outside edge of the riparian stringer. The remaining three plots at each site were placed linearly along the stream course at least $5 \mathrm{~m}$ from the boundary of the previous plot, excluding any major food damaged areas to avoid areas of differing overstory.

The vegetation sampling technique was a modification of that used by Daubenmire and Daubenmire (1968) in their analysis of forest vegetation of Washington and Idaho. On each $5-$ by $25-\mathrm{m}$ macroplot, all trees greater than $2.5 \mathrm{~cm}$ d.b.h. were measured. Relative density, relative dominance, relative frequency, and importance value were estimated using the formulas given by Cottam and Curtis (1956). Woody stems smaller than $2.5 \mathrm{~cm} \mathrm{d.b.h.}$ but taller than $1 \mathrm{~m}$ were recorded as saplings. Those less than $1 \mathrm{~m}$ tall were considered as seedlings and were counted in two 1- by 25-m strips on each side of the macroplot. Twenty $20-$ by $50-\mathrm{cm}$ microplots were established at $2.5-\mathrm{m}$ intervals along the long edges of the macroplot, with 10 microplots along each edge. Crown canopy of each herbaceous species was recorded as a percentage of the microplot area. Forest overstory density was measured using a modified spherical densiometer (Lemmon 1956, 1957). Only the 12 squares forming a plus pattern at the front of the densiometer were used, in order to get a more directional reading. Density readings were taken at the $\mathbf{4}$ corners of each macroplot looking diagonally towards the opposite corner. The same macroplots on both study sites were sampled on June 8, 1977, and again on June 6, 1979. Differences in radial tree growth in each size category and herbaceous cover were tested with the $t$-statistic. Differences in canopy cover between years and plots were tested with a 2-way analysis of variance (ANOVA) (Sokal and Rohlf 1973).

\section{Results}

The primary tree species on both the ungrazed and grazed plots were Fremont cottonwood (Populus fremontii), velvet ash (Fraxinus velutina), and Goodding willow (Salix gooddingii) (Table 1). All other tree species were exclusive to one area or the other. Desert willow (Chilopsis linearis). Arizona walnut (Juglans major), and Rocky Mountain juniper (Juniperus osteosperma) were found only on the ungrazed plot. In contrast, netleaf hackberry (Celtis reticulata), Arizona sycamore (Platanus wrightil), velvet mesquite (Prosopis juliflora), and California buckthorn (Rhamnus californica) were present only on the grazed site. Because a number of stems of California buckthorn were greater than $2.5 \mathrm{~cm} \mathrm{d.b.h.} \mathrm{by}$ 1979 , it was the only species to show a significant change in importance value for any tree species on either site.

Shrubs, saplings, and seedlings differed on both sites. The ungrazed area had 10 velvet ash and 2 cottonwood seedlings and some barberry (Berberis haematocarpa), fly thicket (Brickellia 
Table 1. Tree species importance values on grazed and ungrazed plots, along Little Ash Creek, Ariz., in 1977 and 1979.

\begin{tabular}{|c|c|c|c|c|}
\hline \multirow[b]{2}{*}{ Tree species } & \multicolumn{2}{|c|}{ Ungrazed } & \multicolumn{2}{|c|}{ Grazed } \\
\hline & 1977 & 1979 & 1977 & 1979 \\
\hline $\begin{array}{l}\text { Celtis reticulata } \\
\text { Chilopsis linearis }\end{array}$ & 21.7 & 20.7 & 10.4 & 9.9 \\
\hline Fraxinus velutina & 68.5 & 70.4 & 93.5 & 90.6 \\
\hline Juglans major & 8.3 & 8.3 & & \\
\hline Juniperus osteosperma & 8.3 & 8.3 & & \\
\hline $\begin{array}{l}\text { Platanus wrightii } \\
\text { Populus fremontii }\end{array}$ & 150.6 & 148.9 & $\begin{array}{r}10.2 \\
125.5\end{array}$ & $\begin{array}{r}9.9 \\
119.3\end{array}$ \\
\hline Prosopis juliflora & & & 11.5 & 10.9 \\
\hline Rhammus californica & & & 0 & 17.4 \\
\hline Salix gooddingii & 43.0 & 43.6 & 50.0 & 43.3 \\
\hline
\end{tabular}

sp.), and desert ceanothus (Ceanothus greggi) not found on the grazed site. The grazed site had 43 California buckthorn shrubs and seedlings on the macroplots, whereas, only 1 California buckthorn seedling was found on the ungrazed macroplots. Moreover, the grazed macroplots had 14 juniper saplings and seedlings (Juniperus deppeana and $J$. osteosperma) whereas the ungrazed macroplots had only 5 juniper saplings and seedlings.

Percentage of herbaceous cover was significantly greater on the ungrazed microplots than the grazed microplots ( $P \leq 0.05, t$-test) (Table 2). Percentage of cover also increased on both grazed $(99 \%)$ and ungrazed (54\%) plots from 1977 to 1979.

Tree growth was not affected by grazing practice (Table 3 ). Where size class comparisons are possible, average radial growth was not significantly different $(P \leq 0.05, t$-test $)$ for the grazed versus ungrazed plots. There was, however, a definite difference in the size class distribution of Fremont cottonwood. On the grazed plot there were no cottonwoods with less than $22.5 \mathrm{~cm}$ d.b.h., whereas $\mathbf{4 8 . 3} \%$ of the cottonwoods on the ungrazed plot were less than 22.5 cm d.b.h. This difference is reflected in the percent gain in basal area between the two plots (Table 4). Total basal area (TBA) for cottonwoods on the ungrazed plot increased by $10 \%$ from 1977 to 1979 , whereas on the grazed plot, TBA increased by $5.7 \%$ during
Table 2. Percent herbaceous cover on grazed and ungrazed plots on Little Ash Creek, Ariz. in 1977 and 1979.

\begin{tabular}{|c|c|c|c|c|}
\hline \multirow[b]{2}{*}{ Species } & \multicolumn{2}{|c|}{ Ungrazed } & \multicolumn{2}{|c|}{ Grazed } \\
\hline & 1977 & 1979 & 1977 & 1979 \\
\hline Astragalus spp. & 0.2 & 0.1 & + & 0 \\
\hline Andropogon barbinodis & 0.1 & + & $\mathbf{0}$ & + \\
\hline Bouteloua curtipendula & 1.3 & 0.9 & 0.1 & + \\
\hline Bromus spp. & 0.1 & 0.6 & 0 & 0 \\
\hline Cynodon dactylon & 0 & 0 & 0.1 & 0 \\
\hline Elymus glaucus & 0.1 & 1.3 & 0 & 0.3 \\
\hline Erigeron divergens & 0 & 0 & + & + \\
\hline Erigonum wrightii & +1 & 0 & 0 & $\mathbf{0}$ \\
\hline Galium spp. & + & $\mathbf{0}$ & 0 & $\mathbf{0}$ \\
\hline Gutierrezia sarothrae & 0.6 & 0.8 & 0.6 & 0.6 \\
\hline Machaeranthera spp. & $\mathbf{0}$ & 0 & 0 & + \\
\hline Melilotus alba & 0.8 & 0.7 & 0.3 & 1.3 \\
\hline Muhlenbergia spp. & 0.2 & $\mathbf{0}$ & 0 & 0 \\
\hline Panicum obtusum & $\mathbf{0}$ & 0.5 & 0 & 0 \\
\hline Sitanion hystrix & 0 & 0.2 & 0 & 0 \\
\hline Sonchus asper & 0 & 0.1 & 0 & 0 \\
\hline Total cover & $3.4 \pm 0.8^{2}$ & $5.2 \pm 1.3$ & $1.1 \pm 0.3$ & $2.2 \pm 0.5$ \\
\hline
\end{tabular}

Indicates a trace presence in microplots.

${ }^{2}$ Mean \pm standard error.

the same period.

On the grazed plot, canopy cover was $77.6 \pm 3.9 \%$ (S.E.) in 1977 and $78.5 \pm 3.2 \%$ in 1979 . On the ungrazed plot, overstory canopy cover was $72.1 \pm 3.2 \%$ in 1977 and $74.2 \pm 3.3 \%$ in 1979 . There were no significant differences in overstory canopy cover either between years or between plots (2-way ANOVA, $\alpha \geq 0.05$ ).

\section{Discussion}

The recovery of this riparian area from the effects of grazing has been limited by 3 major floods during the study period. Stream bank erosion has scoured the soil at least $0.5 \mathrm{~m}$, exposing the upper roots of most tree species. Because of the close proximity of all the macroplots we feel that any effects due to flooding were similar on

Table 3. Average radial growth (millimeters) for the dominant riparian trees along Little Ash Creek, Ariz.

\begin{tabular}{|c|c|c|c|c|c|}
\hline \multirow[b]{2}{*}{ Tree species } & \multicolumn{5}{|c|}{ Size classes $(\mathrm{cm})$} \\
\hline & $2.5 \leq$ d.b.h. $<7.5$ & $7.5 \leq$ d.b.h. $<15.0$ & $15.0 \leq$ d.b.h. $<22.5$ & $22.5 \leq$ d.b.h. $<45$ & $45 \leq$ d.b.h. \\
\hline $\begin{array}{l}\text { Ungrazed plot } \\
\text { Fraxinus velutina } \\
\text { Populus fremontii } \\
\text { Salix gooddingii }\end{array}$ & $\begin{array}{c}0.86 \pm 0.16(14)^{\prime} \\
1.40 \\
-\end{array}$ & $\begin{array}{l}0.60 \pm 0.12(9) \\
1.77 \pm 0.23(6) \\
0.75 \pm 0.75(2)\end{array}$ & $\begin{array}{c}1.10 \\
1.76 \pm 0.69(7) \\
1.90 \pm 0.50(2)\end{array}$ & $\begin{array}{l}\overline{-} \\
1.22 \pm 0.28(13) \\
0.93 \pm 0.09(3)\end{array}$ & $\begin{array}{c}\overline{-} \\
- \\
-\end{array}$ \\
\hline $\begin{array}{l}\text { Grazed plot } \\
\text { Fraxinus velutina } \\
\text { Populus fremontii } \\
\text { Salix gooddingii }\end{array}$ & $\begin{array}{c}0.85 \pm 0.18(11) \\
\frac{-}{2.7}\end{array}$ & $\begin{array}{c}0.62 \pm 0.14(10) \\
- \\
-\end{array}$ & $\begin{array}{c}0.73 \pm 0.03(4) \\
-\end{array}$ & $\begin{array}{l}1.10 \pm 0.00(1) \\
1.05 \pm 0.22(8) \\
1.63 \pm 0.61(4)\end{array}$ & $\begin{array}{c}\overline{2.10 \pm 0.80}(3) \\
-\end{array}$ \\
\hline
\end{tabular}

'Mean radial growth \pm standard error $(N)$.

Table 4. Overall growth of dominant riparian tree species along Little Ash Creek, Ariz. from 1977 to 1979.

\begin{tabular}{|c|c|c|c|c|c|}
\hline \multirow[b]{2}{*}{ Tree species } & \multicolumn{2}{|c|}{ Total basal area $\left(\mathrm{m}^{2} / \mathrm{ha}\right)$} & \multirow{2}{*}{$\begin{array}{l}\text { Net gain } \\
\left(\mathrm{m}^{2} / \mathrm{ha}\right)\end{array}$} & \multirow[b]{2}{*}{ Percent gain } & \multirow{2}{*}{$\begin{array}{l}\text { Absolute density } \\
\text { (trees/ha) }\end{array}$} \\
\hline & 1977 & 1979 & & & \\
\hline $\begin{array}{l}\text { Ungrazed plot } \\
\text { Fraxinus velutina } \\
\text { Populus fremontii } \\
\text { Salix gooddingii }\end{array}$ & $\begin{array}{r}3.0 \pm 0.8 \\
34.3 \pm 5.2 \\
5.9 \pm 2.3\end{array}$ & $\begin{array}{r}3.5 \pm 1.0 \\
37.8 \pm 5.3 \\
6.5 \pm 2.5\end{array}$ & $\begin{array}{l}0.46 \pm 0.19 \\
3.46 \pm 0.36 \\
0.59 \pm 0.28\end{array}$ & $\begin{array}{l}15.2 \\
10.2 \\
10.1\end{array}$ & $\begin{array}{l}440 \pm 136 \\
540 \pm 151 \\
120 \pm 52\end{array}$ \\
\hline $\begin{array}{l}\text { Grazed plot } \\
\text { Fraxinus velutina } \\
\text { Populus fremontii } \\
\text { Salix gooddingii }\end{array}$ & $\begin{array}{r}5.3 \pm 1.8 \\
38.3 \pm 12.9 \\
6.4 \pm 4.5\end{array}$ & $\begin{array}{r}5.9 \pm 2.0 \\
40.4 \pm 13.3 \\
7.1 \pm 4.8\end{array}$ & $\begin{array}{l}0.62 \pm 0.23 \\
2.18 \pm 0.65 \\
0.70 \pm 0.37\end{array}$ & $\begin{array}{r}11.7 \\
5.7 \\
10.9\end{array}$ & $\begin{array}{l}520 \pm 256 \\
220 \pm 20 \\
100 \pm 50\end{array}$ \\
\hline
\end{tabular}

'Mean of Values from the four macroplots \pm standard error. 
all macroplots.

Herbaceous cover was at least double that on the ungrazed plot than on the grazed plot, but still $95 \%$ of the total soil surface is bare sand or gravel. This agrees with the data of Crouch (1978), who found a much greater cover of grasses and forbs on an ungrazed versus a grazed cottonwood bottomland in northeastern Colorado. The difference in herbaceous cover is not a result of a difference in overstory cover, because both sites had equal overstory cover values. It is probably a result of differences in grazing pressure.

Information on riparian tree species growth is extremely limited. Average radial growth in plains cottonwood (Populus deltoides var. occidentalis) ranges from 1.7 to $2.5 \mathrm{~cm}$ a year in dry habitats, and up to $7.0 \mathrm{~cm}$ a year in wet habitats (Fowells 1965). The growth of Fremont cottonwood in this study was similar to that of plains cottonwood on dry sites. In northeastern Colorado, basal area decreased on a grazed plot $18 \%$ but increased $16 \%$ on an ungrazed plot (Crouch 1979). Along Little Ash Creek, basal areas increased on both sites from 1977 to 1979 . However, a look at tree size distribution indicates many more younger cottonwoods on the ungrazed site as well as some stand reproduction. One might expect continued increases on the ungrazed plot for a long period but a decrease on the grazed plot as the older trees decline. All the trees on both study sites probably were present before the establishment of the exclosure, with the possible exception of the single cottonwood in the smallest size cla ss. Crouch (1979) estimated that an $18-\mathrm{cm}$ d.b.h. cottonwood is approximately 30 years old. Cottonwood and ash seedling reproduction, however, is higher on the ungrazed plot, further indicating the potential recovery of this area from grazing, particularly because cottonwood and ash seedlings are known to be sought-after browse (Glinski 1977, Martin 1979).

In conclusion, differences between these two sites, primarily resulting from the exclusion of grazing pressure, are subtle at present. This indicates that a more complete recovery will require many more years of grazing protection.

\section{Literature Cited}

Ames, Charles R. 1977. Wildlife conflicts in riparian management: Grazing. p. 49-51. In: Importance, preservation and management of riparian habitat: A symposium. R.R. Johnson and D.A. Jones, technical coordinators. USDA Forest Serv. Gen. Tech. Rep. RM-43, Rocky Mountain Forest and Range Exp. Sta., Fort Collins, Colo.
Cottam, C., and J.T. Curtis. 1956. The use of distance measures in phytosociological sampling. Ecology 37:451-460.

Crouch, Glenn L. 1978. Effects of protection from livestock grazing on a bottomland wildife habitat in Northeastern Colorado. p. 118-125. In: Lowland river and stream habitat in Colorado: A symposium. W.D. Gracil and S.J. Bissell, technical coordinators. Colorado Chapter Wildlife Society and Colorado Audubon Council. Greeley.

Crouch, Glenn L. 1979. Long-term changes in cottonwoods on a grazed and ungrazed plains bottomland in northeastern Colorado. USDA Forest Serv. Res. Note RM-370. Rocky Mountain Forest and Range Exp. Sta., Fort Collins, Colo.

Daubenmire, R., and Jean B. Daubenmire. 1968. Forest vegetation of eastern Washington and northern Idaho. Washington Agr. Exp. St. Tech. Bull. 60:1-104. Pullman.

Davis, Gary A. 1977. Management alternatives for the riparian habitat in the southwest. p. 59-67. In: Importance, preservation and management of riparian habitat: A symposium. R.R. Johnson and D.A. Jones, technical coordinators. USDA Forest Serv. Gen. Tech. Rep. RM-43. Rocky Mountain Forest and Range Exp. Sta., Fort Collins, Colo.

Fowells, H.A. 1965. Silvics of forest trees of the United States. USDA Forest Serv. Agr. Handbook 271. Washington, D.C.

Glinski, Richard L. 1977. Regeneration and distribution of sycamore and cottonwood trees along Sonoita Creek, Santa Cruz County, Arizona. In: Importance, preservation and management of riparian habitat: A symposium. R.R. Johnson and D.A. Jones, technical coordinators. USDA Forest Service Gen. Tech. Rep. RM-43, 217 p. Rocky Mountain Forest and Range Exp. Sta., Fort Collins, Colo.

Lemmon, Paul E. 1956. A spherical densiometer for estimating forest overstory density. Forest Sci. 2:314-320.

Lemmon, Paul E. 1957. A new instrument for measuring forest overstory density. J. of Forestry 55:667-668.

Martin, S. Clark. 1979. Evaluating the impacts of cattle grazing on riparian habitats. p. 35-38. In: Forum-grazing and riparian/stream ecosystems, O.B. Cope, editor. Trout Unlimited, Inc. Denver, Colo.

Platts, William S. 1979. Livestock grazing and riparian/stream ecosystems and overview. p. 39-45. In: Forum-grazing and riparian/stream ecosystems, O.B. Cope, editor. Trout Unlimited, Inc.

Sokal, Robert R., and F. James Rohlf. 1973. Introduction to biostatistics. W.H. Freeman and Co., San Francisco, Calif.

Thomas, Jack Ward, Chris Maser, and Jon E. Rodrek. 1979. Riparian zones in managed rangelands - their importance to wildlife. p. 21-30. In: Forum-grazing and riparian/stream ecosystems, O.B. Cope, editor. Trout Unlimited, Inc. Denver, Colo.

Turner, Raymond M., Lee H. Applegate, Patricia M. Bergthold, Steve Gallizioli, and S. Clark Martin. 1980. Arizona range reference areas. USDA Forest Serv. Gen. Tech. Rep. RM-79. Rocky Mountain Forest and Range Exp. Sta., Fort Collins, Colo. 